\title{
Public speaking as a tool for developing students' communication and speech skills
}

\author{
Svetlana Bylkova ${ }^{1^{*}}$, Elena Chubova ${ }^{2}$, and Igor Kudryashov ${ }^{3}$ \\ ${ }^{1}$ Don State Technical University, 1, Gagarin Sq., Rostov-on-Don, 344003, Russia \\ ${ }^{2}$ Don State Technical University, 1, Gagarin Sq., Rostov-on-Don, 344003, Russia \\ ${ }^{3}$ Southern Federal University, 105 / 42, Bolshaya Sadovaya Str., Rostov-on-Don, 344006, Russia
}

\begin{abstract}
Public speaking involved the performance of one person (speaker, rhetorician) in front of the audience, with the speaker assigned an active role, and the audience - a passive one. At the present stage, the form of public speech communication changes from monologue to dialogic and is implemented in active types and forms of dialogue - dispute, discussion, dispute, interview, debate, etc. Means of dialogization, including questions (clarifying, rhetorical, etc.) that allow you to establish contact with the audience, are designed to arouse interest in speech and maintain the attention of listeners. The development of rhetorical skills occurs only in the case of a successful public speech, that is, the achievement of the goal. In this regard, it makes sense to consider the structure of public speech preparation, which includes three stages: pre-communicative (preparatory), communicative (basic) and post-communicative (analytical). The purpose of this study is to determine the conditions for the forming and developing technical university students' rhetorical skills in the course of determining the complex of professionally significant public speaking skills of students of a technical university. The research objectives are formed in accordance with the logical sequence of studying materials on this issue, namely: 1) characterizing the concept, content and structure of public speaking as a genre of oral professional communication; 2) identifying the list of factors that ensure effective public speaking; 3 ) describing the methodology for the formation of rhetorical skills necessary for the implementation of an effective public speech; 4) displaying the positive dynamics of students' rhetorical skills.
\end{abstract}

\section{Introduction}

Intensive changes in society related to information technologies are becoming extremely important. The educational system, characterized by its fundamental nature and stability, must nevertheless respond to the global challenges of our time. The demand for graduates of higher educational institutions is provided not only and not so much by their professional skills in a particular field, but also by the ability to master the techniques and means of effective, including public communication, skills of working with scientific and technical,

\footnotetext{
*Corresponding author: svetbyl17592@rambler.ru
} 
journalistic and official business texts, the ability to interact in a team, prevent conflicts, etc.

Most employers, both Russian and foreign, prefer those employees who have the skills of oral communication and self-presentation when hiring. It is noted that employees who are able to build effective oral communication are successful in their professional activities and achieve significant progress on the career ladder in a fairly short time frame [1]. In addition, they are motivated for further training and self-education. The development of communication skills in students of different levels of training involves the use of certain pedagogical approaches, for example, project training [2]. Project activity, being a joint cognitive and creative process, has a common goal, which is realized at the final stage in the form of presentation and public speech.

At various times, linguists, sociologists, and psychologists have turned to the study of public speech. They all found problems and offered solutions. Thus, a number of scientists have studied the influence of speakers' anxiety on the acoustic characteristics of their speech, and, as a result, on the success of the entire speech [3]. An important component of any public speech is the correspondence of the speaker's gestures to the content of the speech message [4]. A number of researchers agree that public speaking skills should be taught already in primary school, since these skills also serve as a tool for teaching and evaluating knowledge. It is necessary to take into account an equally important factor of various speech training programs-the reduction of children's anxiety before speaking [5]. In order to develop communication skills through public speaking, students use specially designed programs, including in the form of training, which allow them to competently make informative public speeches [6]. It is interesting that the problems identified in the preparation of public speeches in schoolchildren are similar in students, namely, the anxiety that occurs when they speak to an unfamiliar audience [7]. Improving oral communication skills and reducing the anxiety of public speaking is to develop self-efficacy, that is, people's judgment of their abilities and ability to organize and execute the chains of actions required to achieve pre-determined types of performance results [8]. We have already noted that employers consider oral communication and presentation skills to be among the main ones that they take into account when applying for a job, since in the future these employees demonstrate high productivity results and they are more successful in career development [9-11]. The above facts form the relevance of our research.

In recent years, there has been an active transition from interpersonal communication to Internet interaction, which in turn leads to the loss of such important skills as the use of intonational means of expression, non-verbal means of communication, the construction of a logical and clear speech utterance, etc. Russian Language and Culture of Speech, Business Communications, Copywriting, Business Rhetoric and Corporate Culture, and Language communication in professional activities (in Russian and foreign languages) are included in the curriculum of such disciplines as "Culture of oral and written speech», «Culture of Public speaking of an engineer», «Russian language and Culture of Speech», «Business Communications», «Copywriting», «Business Rhetoric and Corporate Culture», and «Language communication in professional activities» [12]. Within the framework of the taught disciplines, the practice of teaching rhetoric is carried out, built in accordance with the requirements of professionally oriented speech communication, which contributes to the improvement of the level of speech culture, the formation of effective communication skills.

The main stage in the structure of a public speech is the delivery of a speech, which, as we have already pointed out, is implemented in a certain context. The context is determined by the specific situation, the target audience, the speaker's communication intent, and the topic. Speech performance implies compliance with certain norms and standards and is characterized by certain nonverbal skills: behavioral and visual. From all the extensive tools 
used by experienced speakers, two groups can be distinguished. The first category includes phonation techniques, including tempo, timbre, volume and melody of speech, dialect and social features, and articulation of sounds. The second group includes kinetic (behavioral) techniques - gestures, postures, facial expressions. There is a certain set of standard interactive gestures that enhance the meaning of the spoken speech, attract the attention of listeners. It is necessary to take into account the factor of interaction of speech and gestures, ignoring it can lead both to an increase in the audience's interest in the speech, and to its decrease. It is about the appropriateness of using gestures in the context of a speech [14]. Interaction with the audience during a speech requires more careful consideration, since the inability to establish contact with the audience, to read their reaction to spoken thoughts is the main reason for the emergence of communication barriers. The second key task of the rhetorician is to overcome the fear of speech. It can be eliminated by connecting the motivation of the student, that is, his willingness to communicate, to conduct a dialogue in a specific situation. The dialogical interaction between the speaker and the audience helps to activate the cognitive process in which thoughts and feelings coincide. By asking questions, the speaker establishes a close connection with the audience, discusses controversial theses, and exchanges emotions.

In the educational process, the successful development of communication skills is carried out in team interaction, since this format implies a discussion format for discussing problematic issues. An important positive result of the practical application of the group form of work in the educational process is the creation of the most comfortable conditions for the communication of students, the development of interpersonal relationships. It is group forms of work that are an effective means of developing students' communicative competencies; contribute to the formation of adequate self-esteem, and, as a result, selfrealization of their «Self». The logical conclusion of group interaction is reflexive activity, which can be carried out on the cognitive, emotional levels and the level of one's own ideas. Conscious control of the communication interaction of partners and their own behavior makes it possible to make the necessary adjustments in order to avoid repeating the identified mistakes [15]. In addition, active team interaction has a positive effect on the development of an extremely important personal quality - self-efficacy. Self-efficacy is greatly influenced by one's own experience of both success and failure in trying to achieve the desired results. No less effective is the observation of the activities of other people. In the study group, students carefully monitor the achievements of their classmates, noting the conditions and factors that positively affect the achievement of their tasks.

Another problem is the fear of getting a result that does not meet the expectations of both the future speaker and the expectations of others. Throughout the entire period of study at the university, students gradually develop an evaluative opinion about each other, as well as an understanding of what can be expected from a particular student. The mechanism of forming the image of a person depends on many factors, including experience, stereotypical thinking, spiritual and moral development. Everyone strives to create a positive image in group interaction, to show the best sides of their personality, expecting a positive assessment from others. And from this point of view, public speaking is assessed by students as a certain risk. Thus, we come to another tool that helps to overcome certain «clamps» in public speaking - self-presentation (self-presentation). Moreover, we are talking exclusively about natural (natural) self-presentation, and not about artificial, which works exclusively in a certain context and can collapse at any time.

In order to conduct a successful self-presentation, the student must take into account several factors, namely: he must be motivated to actively influence the perception of the audience; know what specific behavior will lead to the desired impression and, of course, be able and willing to accept the desired behavior. At the same time, it is important to maintain a balance between the representations of your positive image and the adequate 
perception of it by others. An auxiliary tool for strengthening important theses and focusing on them in a public speech is a presentation, especially for people who experience certain difficulties at the initial stages of public interaction. What are the advantages of the presentation? First, it is an effective way to visualize information: it helps not only to perceive information at a deeper cognitive level, but also to have the necessary impact on the audience. Secondly, the presentation is a pedagogical tool for training novice communicators. But if there are positive aspects, there are also so-called «pitfalls» that expand the complex of communicative tasks. It is necessary to synchronize the relations between the verbal, gestural and visual components of the presentation, combining them into a triune channel of information transmission. The implementation of the project method in the educational process also contributes to the formation and development of public speaking skills. Along with the development of research skills, students also master rhetorical skills. For public protection, students present the product of the work accompanied by an oral message, which clearly sets out information about the results of the project activities. Any completed public performance requires reflection and analysis. In the educational process, it is enough to develop evaluation criteria for the blocks: evaluation of the speaker's speech (speech, gestures, facial expressions, etc.) and evaluation of the presentation. Both students and teachers can evaluate the performance in the complex. It is important to follow up the general discussion of the results, where the main component of the evaluation activity is the speaker's self-assessment. It is necessary to understand what prevented or, on the contrary, helped in the course of the speech? What factors played a decisive role? How has the attitude of others changed? How much has your self-image changed?

\section{Materials and methods}

This research is based on the assumption that public speaking is an effective tool for the development of both communication and speech skills of future specialists in any field of activity focused on social interaction. We consider it important to note that public speech as a form of business interaction, regardless of the chosen genre, whether it is a report, informative, trade or welcome speech, provides ample opportunities for getting out of theory into practical activity both in a specific business sphere, as well as in the field of education, culture, and intercultural communication with the involvement of a complex of studied disciplines and inter-university interaction, which was noted above. Public speech is associated with the pragmatics of speech communication, since it involves the exchange of thoughts, the transfer of information using language. The effectiveness of the speaker's speech is related to two aspects - speech and text. They, in turn, are based on the general communicative qualities of speech and the maxims of speech communication. Thus, public speech is an indicator of the level of mastery of the speaker's communicative and speech competence. That is, it demonstrates the ability of the student to build and correct speech in accordance with the content of various concepts: communicative, genre, stylistic, logical norms. Since information is necessary to create your own text, the role of mastering modern information technologies and awareness of the importance of factual accuracy increases. Of particular importance is the eristic subcompetence, which focuses on the knowledge of the basics of the theory of the dispute, the skills and skills of its constructive conduct, as well as the oratorological subcompetence, which is based on the concepts of the rhetorical canon and the image of the rhetorician, the knowledge of non-verbal means.

The methodological basis of this study is the works on problems related to communication, works in the field of research of the language of business communication. The range of works that turned out to be necessary in terms of ensuring the theoretical validity of the study also includes studies on the theory and practice of sociolinguistics and 
pragmalinguistics [16-17]. A significant segment of the theoretical platform is formed by scientific works on rhetoric, argumentation theory, speech culture, pedagogy, and methods of teaching humanities. We used the method of analysis when working with scientific and educational literature, when considering and selecting models of subject-language integration that are relevant for teaching rhetorical canons, language communication in the professional sphere; the method of analogy, which allowed us to compare the data obtained in the course of experiments with previously put forward theoretical postulates. Empirical methods were also used, for example, observation, comparison of data used in the Russian and foreign practice of teaching public speaking, as well as in the study of the results of pedagogical experiments, a survey and a questionnaire method. At several stages: ascertaining, forming and control - we resorted to the experimental method. Also important for the study was the statistical method used by the authors of the article in the process of collecting and processing the results of student surveys and tests, in the qualitative analysis of practical tasks and written works of students, as well as in the analysis of the results of the experiment.

The authors of the study summarized the information about the structural and content components of the rhetorical text, focusing on the concept of public speech. Following E. N. Malyuga, S. N. Orlova [18], and K. Shokhayeva [19], we identified a range of factors that ensure the effectiveness of public speaking. The article describes the methodology for the formation of rhetorical and communicative skills among students of a technical university, revealing the specifics of thematic blocks of humanities-oriented disciplines designed to develop professionally significant skills in the field of public speaking. They presented statistical data reflecting the positive dynamics of the development of rhetorical skills among first-and second-year students in the study of a number of disciplines covering the art of eloquence.

\section{Discussion}

In 2019, teachers of the Department of «Documentation and Language Communication» of the Don State Technical University, working with first-year students, noted the emergence of problems related to the speech and communication activities of students. Most of the «sore» points were more or less related to the dialogization of communication. Based on the observation of colleagues and our own pedagogical experience, we outlined their circle: lack of active listening skills; inability to respond to emotions; emotionless speech; inability to describe their feelings; lack of eye contact with the interlocutor (and this is one of the main tools for attracting attention and establishing contact between the speaker and the listener); lack of interest in the topic, even if it was chosen independently; inability to use the capabilities of the voice apparatus; inability to perceive super-phrasal unity; priority is given to the «telegraph» style of communication; lack of long-term memory, systematic thinking, fear of speech, lack of skills to participate in dialogue and polylogue, and others.

The information obtained served as a starting point for creating a methodology that allows you to develop, and sometimes form, social, communication and speech skills as effectively as possible. The value of this method lies in the active inclusion in the educational process of such components as emotional and personal perception of information, thinking, actions, speech and in the formation of communicative and social experience, improving rhetorical skills, skills of self-management of behavior, including in the event of conflicts of different directions.

The purpose of our methodology is to form a person who is able to think independently, to develop an original solution to a problem relevant to a particular area of life, to formulate it accurately and clearly for everyone, to arouse interest in it among the relevant persons and to make them like-minded people. Thus, the educational process is organically 
interwoven with educational and developmental goals, educational and practical. For their implementation methods are utilized project-based learning in conjunction with the play and active learning methods, since they are, in our opinion, are an effective vehicle for the development of not only speech, but also the communication skills required for the formation of universal competencies outlined in the Federal educational standards of higher education:

- ability to carry out social interaction and sell their role in the team;

- ability to carry out business communication in oral and written forms in the state language of the Russian Federation and foreign language (s));

- ability to manage your time, build and implement a trajectory of self-development based on the principles of self-education throughout your life.

The methods outlined above are used as independent pedagogical developments, and in combination with traditional ones. The use of active learning methods is explained by the need to activate the cognitive activity of students or increase it. We distinguish six types of activity in the educational process: thinking, emotional and personal perception of information, action, speech, reflection and feedback. Depending on the type of methods used by teachers, either one of the types or a combination of them is implemented in the framework of training meetings. In order to see which and how many of the six types of activity of students are shown in the classroom, we turn to the following Table 1.

Table 1. The relationship between the forms of training sessions and the types of activity of students.

\begin{tabular}{|c|c|c|c|c|c|c|}
\hline \multirow{2}{*}{$\begin{array}{c}\text { Training } \\
\text { session } \\
\text { form }\end{array}$} & thinking & action & speech & $\begin{array}{c}\text { Types of activities involved in the learning process } \\
\text { and } \\
\text { personal } \\
\text { speech } \\
\text { perception }\end{array}$ & reflection & feedback \\
\hline $\begin{array}{c}\text { traditional } \\
\text { lecture }\end{array}$ & + & - & $\begin{array}{c}\text { inner } \\
\text { speech }\end{array}$ & + & - & - \\
\hline $\begin{array}{c}\text { laboratory } \\
\text { work }\end{array}$ & + & + & - & - & - & - \\
\hline discussion & + & - & + & + & + & + \\
\hline $\begin{array}{c}\text { business } \\
\text { game }\end{array}$ & + & + & + & + & + & + \\
\hline debates & + & + & + & + & + & + \\
\hline training & + & + & + & + & + & + \\
\hline excursion & - & - & - & + & - & - \\
\hline
\end{tabular}

The Table 1 clearly demonstrates the advantages of the activity approach in teaching and the inclusion of active and problem-based learning methods in it.

Let's name another important component of education-information, more precisely, residual knowledge, or information that is stored in long-term memory. Since memory is based on speech skills - reading, listening, writing, and speaking skills - it is obvious that in high school it is necessary to improve all these skills, given that the process of memorization relies on thinking, imagination, and attention. Therefore, it is advisable to teach students the techniques of semantic reading, the development of attention, memory and creative thinking.

Starting to work with new students, during the 2019-2020 and 2020-2021 academic years, we conducted a questionnaire-a survey aimed at identifying what percentage of important information students remember after classes held in various formats. Experiments in 25 focus groups of students of various faculties: «Innovative Business and Management», «Machine-building Technologies and Equipment», «Computer Science and Computer Engineering», «Media Communications and Multimedia Technologies», «Social 
and Humanitarian» and «Psychology, Pedagogy and Defectology» - confirmed the hypothesis that only with active activity the percentage of learning material assimilation is high. Table 2 presents the generalized results of questionnaires and surveys conducted in groups after thematic lectures, independent work with information sources, presentations of the studied sources, and group training «Rules and principles of working with scientific, reference, and popular science literature».

Table 2. Experimental data on the degree of educational material assimilation.

\begin{tabular}{|c|c|c|c|}
\hline № & Forms of information perception & $\begin{array}{c}\text { \% of information } \\
\text { assimilation }\end{array}$ & $\begin{array}{c}\text { number of } \\
\text { students }\end{array}$ \\
\hline 1 & Traditional lecture & $24 \%$ & 431 \\
\hline 2 & Individual work & $47 \%$ & 431 \\
\hline 3 & $\begin{array}{c}\text { Pronouncing the material } \\
\text { (making a presentation) }\end{array}$ & $66 \%$ & 431 \\
\hline 4 & Personal participation (group training) & $81 \%$ & 431 \\
\hline
\end{tabular}

The data in Table 2 convince us of the priority of the activity approach, the individualization of the learning process. Therefore, we prefer active educational methods. The advantages of game techniques and procedures (a lecture together, a lectureconversation, a lecture with planned mistakes), business games, trainings, simulation models and games are that students:

- are stimulated to be active regardless of their desire (activation, attention, thinking, memory;

- are involved in the learning process throughout the class;

- independently creatively develop solutions,

- help to increase the degree of motivation and emotionality of their fellow students.

So, at the trainings dedicated to the possibilities of human memory, students:

- gain knowledge about the types of memory (genetic, motor (motor), emotional, figurative (visual), eidetic (visual and auditory), verbal-logical-processing of verbal information, the selection of the most significant from it and the retention of thoughts in memory, not words; arbitrary (organizational), short-term and long-term and operational (associated with the process of rapid processing of multiple information);

- learn the techniques of successful memorization;

- learn how to deal with forgetting the essential, significant in the educational material, that is, how to properly use the «resources» of memory.

Since the characteristics of each person's memory are determined by the characteristics of their activities aimed at achieving specific goals, the humanities courses focus on such characteristics as duration, volume, accuracy, speed, and readiness to reproduce - all of them are important both in educational and professional activities. For the development of long-term memory, the ability to reflect, as well as to identify the degree of influence of information content on the speech and communication skills of students for three focus groups (let's call them group A, group B, group C), television and Internet interviews were included in the classroom and independent work. They are nothing but a powerful tool, one of the most effective ways to form cognitive descriptors, meta-languages, as well as general competencies of future professionals: the interview, from the point of view of pragmatics, performs two functions - communication and creating speech influence. Today, the interview is both a tool and a result of media education, so the level of speech culture of communicants comes to the fore. As an experimental method, we offered the participants of groups A and B intellectual interviews with T. Chernigovskaya and V. Pozdner. When discussing television interviews, students noted that figurative speech (combining scientific terminology, metaphorical comparisons, contact-setting and contact-supporting formulas), the level of education, the speech culture of the interviewees, the ability to use «language 
empathy», contributed to the creation of an atmosphere favorable for both polemical discourse and intellectual dialogue, which is based on informative exchange.

Group B was asked to independently choose popular presenters on the YouTube channel or bloggers who are interviewed. This is how the content was formed for the development of communication and speech skills in students of this group. It includes Internet interviews with Yuri Dudya, issues, «Gentle Editor», «Cannon». These videos, in our opinion, are characterized by a superficial view of important social, political, and economic problems, a liberal agenda, and sometimes a distortion of facts. When discussing online interviews, only $10 \%$ of students noted the presence of numerous lexical repetitions, parasitic words, repeated violations of morphological norms, and an abundance of colloquial and emotionally-colored vocabulary in the speech of the presenters. $90 \%$ of the student audience of this focus group perceived the bloggers' speech as a reference or corresponding to the norms of the students' language environment.

Participants of groups A, B, and C within the framework of project research activities, working independently, in a group, forming dyads and triads, deciphered video recordings of interviews and conducted a linguistic and stylistic analysis of the text; wrote reasoned essays on the topics raised in the interview. Thanks to a powerful set of tools for the development of communication and speech skills-methods and techniques (oral communication, debates, business games, discussions, trainings, interviews, presentation and self-presentation, letter-reflection), designed to form and develop communication and speech skills in students of the 1st and 2nd courses of the Don State Technical University, students learn educational material that can be structured within the XII thematic blocks, which are reflected in Table 3.

Table 3. Content of modules of the interdisciplinary cycle «Public Speaking».

\begin{tabular}{|c|c|c|c|}
\hline № & Module name & Planned result & $\begin{array}{c}\text { Pedagogical methods } \\
\text { and techniques }\end{array}$ \\
\hline 1 & $\begin{array}{l}\text { I an in the mirror of } \\
\text { communication }\end{array}$ & $\begin{array}{c}\text { - awareness of the role of ethos in one's own } \\
\text { life and the life of society; } \\
\text { - awareness and fixation of their speech- } \\
\text { thinking abilities; } \\
\text { - developing the long-term memory; } \\
\text { - the ability to include phatic formulas in } \\
\text { one's own speech; } \\
\text { - the skill of «keeping eye contact» in the } \\
\text { process of communication; } \\
\text { - the skill of interpreting non-verbal means }\end{array}$ & $\begin{array}{l}\text { - the long-term memory } \\
\text { training «Snowball», } \\
\text { «Method of word } \\
\text { associations», «Original } \\
\text { acquaintance»; } \\
\text { - a letter-reflection; } \\
\text { - the personal diary }\end{array}$ \\
\hline 2 & $\begin{array}{l}\text { Forms and types of } \\
\text { speech: oral and } \\
\text { written speech; } \\
\text { external and internal } \\
\text { speech }\end{array}$ & $\begin{array}{c}\text { - knowledge of speech mechanisms; } \\
\text { - improving the skill of targeting in public } \\
\text { speaking; } \\
\text { - possession of a set of language skills that } \\
\text { ensure compliance with the language rules for } \\
\text { constructing a speech utterance that } \\
\text { corresponds to the «speech standard» } \\
\text { (language norm); } \\
\text { - the ability to create texts within the target } \\
\text { setting and a given topic }\end{array}$ & $\begin{array}{l}\text { - problem situation; } \\
\text { - brainstorming «The } \\
\text { similarities and differences } \\
\text { of oral and written forms } \\
\text { of speech»; } \\
\text { - linguistic and } \\
\text { psychological } \\
\text { experiments; } \\
\text { - reflective writing }\end{array}$ \\
\hline 3 & Speech technique & $\begin{array}{l}\text { - knowledge of the speech apparatus } \\
\text { mechanism; } \\
\text { - the skill of using the speech apparatus to } \\
\text { effectively influence the interlocutors; } \\
\text { - mastering the perspective of voice pitch } \\
\text { distribution }\end{array}$ & $\begin{array}{l}\text { - exercises for developing } \\
\text { the muscles of speech } \\
\text { breathing, the expansion } \\
\text { of the high-altitude and } \\
\text { dynamic range of the } \\
\text { voice, the flight of the } \\
\text { voice; } \\
\text { - exercises with the } \\
\text { pronunciation of poetic } \\
\text { texts; } \\
\text { - reflective writing }\end{array}$ \\
\hline
\end{tabular}




\begin{tabular}{|c|c|c|c|}
\hline 4 & $\begin{array}{l}\text { Listening as a type of } \\
\text { speech activity }\end{array}$ & $\begin{array}{l}\text { - knowledge of your strengths and weaknesses as } \\
\text { a listener; } \\
\text { - knowledge of the main types of listening; } \\
\text { - knowledge of the rules and barriers of } \\
\text { listening; } \\
\text { - mastering attention-stimulating techniques; } \\
\text { - possessing the skill of effective listening; } \\
\text { - the ability to ask different types of questions; } \\
\text { - the ability to use different response cues; } \\
\text { - the ability to use various ways of implementing } \\
\text { speech functions (expression of consent, } \\
\text { disagreement, doubt, displeasure, polite refusal, } \\
\text { etc.); } \\
\text { - the ability to decode the addressee's speech } \\
\text { intent }\end{array}$ & $\begin{array}{l}\text { - game exercises aimed at } \\
\text { improving non-reflexive and } \\
\text { reflexive listening } \\
\text { - transcript of a lecture } \\
\text { recorded on a dictaphone; } \\
\text { - analysis of the } \\
\text { introduction to the lecture } \\
\text { - reflective writing }\end{array}$ \\
\hline 5 & $\begin{array}{l}\text { Semantic reading as a } \\
\text { type of speech activity }\end{array}$ & $\begin{array}{l}\text { - knowing the types of reading (introductory, } \\
\text { selective, learning, reflexive, rational and } \\
\text { emotional, functional and aesthetic, reproductive } \\
\text { and creative, leisure and business, etc.); } \\
\text { - knowing the specifics of semantic reading; } \\
\text { - possessing the skill of evaluating information } \\
\text { and emotional response to some content; } \\
\text { - the ability to formulate questions; } \\
\text { - reflecting on the content or form of the text }\end{array}$ & $\begin{array}{c}\text { - dialogue with the author; } \\
\text { - reading with stops; } \\
\text { - reading with notes; } \\
\text { - keywords; } \\
\text { - thin and thick questions; } \\
\text { - creating a cluster; } \\
\text { - collective compilation of } \\
\text { tables, presentations; } \\
\text { - maintaining a reader's } \\
\text { diary, thematic (genre) card } \\
\text { file; } \\
\text { - reflective writing }\end{array}$ \\
\hline 6 & Inventing thoughts & $\begin{array}{l}\text { - the ability to formulate the topic of the } \\
\text { statement; } \\
\text { - the skill of using the method of word } \\
\text { associations to find an idea; } \\
\text { - learning to perform rhetorical operations of } \\
\text { «inventing thoughts» based on imitation of } \\
\text { patterns }\end{array}$ & $\begin{array}{c}\text { - brainstorming «Find your } \\
\text { topic»; } \\
\text { - role-playing games } \\
\text { «Position», «Interview»; } \\
\text { - exercise «I pull out the } \\
\text { idea from someone else's } \\
\text { statement»; } \\
\text { - training on tracking the } \\
\text { first results; } \\
\text { - reflective writing }\end{array}$ \\
\hline 7 & $\begin{array}{l}\text { The logical aspect of } \\
\text { rhetoric }\end{array}$ & $\begin{array}{l}\text { - improving the ability to use concepts; } \\
\text { - developing the skill of editing statements from } \\
\text { the logical point of view; } \\
\text { - forming the ability to «create one's own } \\
\text { thoughts» in accordance with the laws of logic }\end{array}$ & $\begin{array}{l}\text { - training on the definition } \\
\text { of logical errors in the } \\
\text { operation of concepts; } \\
\text { - conceptual and } \\
\text { terminological game; } \\
\text { - logical tasks; } \\
\text { - independent work } \\
\text { (listening to one's own } \\
\text { statement, extracting several } \\
\text { concepts from it, giving a } \\
\text { definition of each of them } \\
\text { by checking these } \\
\text { definitions in one of the } \\
\text { explanatory dictionaries; } \\
\text { - reflective writing }\end{array}$ \\
\hline 8 & Theses and arguments & $\begin{array}{l}\text { - the ability to formulate one's own theses and } \\
\text { find them in scientific and journalistic texts; } \\
\text { - the ability to distinguish between judgments } \\
\text { and sentences, to find the subject and predicate in } \\
\text { judgments; } \\
\text { - the ability to distinguish between belief and } \\
\text { proof; } \\
\text { - the ability to express the same idea in different } \\
\text { language means; } \\
\text { - the ability to see errors in «putting the thesis» } \\
\text { in someone else's text; } \\
\text { - the ability to choose effective arguments to } \\
\text { achieve the task; } \\
\text { - getting to know the constructive dispute skills; } \\
\text { - the ability to improvise in argumentation }\end{array}$ & $\begin{array}{c}\text { - debate; } \\
\text { - business games; } \\
\text { - disputes; } \\
\text { - role-playing games; } \\
\text { - exercise with-syllogisms; } \\
\text { - logical tasks; } \\
\text { - role-playing game } \\
\text { «Detectives»; } \\
\text { - playing game «Mafia»; } \\
\text { - reflective writing }\end{array}$ \\
\hline
\end{tabular}




\begin{tabular}{|c|c|c|c|}
\hline 9 & $\begin{array}{c}\text { Types of dispute: } \\
\text { polemic, discussion, } \\
\text { debate }\end{array}$ & $\begin{array}{c}\text { - knowledge of dispute techniques and } \\
\text { defense techniques in a dispute; } \\
\text { - the ability to conduct an argument; } \\
\text { - the ability to find tricks of opponents in a } \\
\text { dispute; } \\
\text { - knowledge of negotiation tactics; } \\
\text { - the ability to use conflict resolution } \\
\text { strategies }\end{array}$ & $\begin{array}{c}\text { - analysis of the technique } \\
\text { of disputing literary } \\
\text { heroes; } \\
\text { - collective trainings for } \\
\text { practicing dispute } \\
\text { techniques; } \\
\text { - debate; } \\
\text { - business games; } \\
\text { - disputes; } \\
\text { - role-playing games } \\
\text { «Hiring», «Appeal»; } \\
\text { - reflection writing } \\
\end{array}$ \\
\hline 10 & $\begin{array}{l}\text { Visual and expressive } \\
\text { means of language }\end{array}$ & $\begin{array}{c}\text { - forming or developing the text editing skill } \\
\text { in terms of expressiveness; } \\
\text { - improving the ability to make contact with } \\
\text { other people and decorate your speech; } \\
\text { - developing the ability to check and correct } \\
\text { the text in essence, subjecting it to literary } \\
\text { editing; } \\
\text { - forming and developing the ability to build } \\
\text { a thesis in accordance with the style and genre } \\
\text { of the statement }\end{array}$ & $\begin{array}{c}\text { - games for the } \\
\text { development of creative } \\
\text { imagination; } \\
\text { - binomial fantasies; } \\
\text { - edit one's own and other } \\
\text { people's texts; } \\
\text { - rhetorical analysis of } \\
\text { texts; } \\
\text { - linguistic analysis of } \\
\text { texts; } \\
\text { - reflective writing }\end{array}$ \\
\hline 11 & $\begin{array}{l}\text { Public speech: types, } \\
\text { genres, composition }\end{array}$ & $\begin{array}{c}\text { - developing the skill of creating one's own } \\
\text { text in accordance with the requirements of } \\
\text { the style and genre; } \\
\text { - developing the ability to make a report on a } \\
\text { scientific topic }\end{array}$ & $\begin{array}{c}\text { - creating a group } \\
\text { abstract; } \\
\text { - defending the abstract; } \\
\text { - lecture-press conference; } \\
\text { - preparing a text on a } \\
\text { scientific topic (a popular } \\
\text { scientific article, a note } \\
\text { about a scientific } \\
\text { discovery, an interview } \\
\text { with a scientist; } \\
\text { - reflective writing }\end{array}$ \\
\hline 12 & Public speaking & $\begin{array}{l}\text { demonstrating the formed speech and } \\
\text { communication skills }\end{array}$ & $\begin{array}{l}\text { - Public Speaking } \\
\text { Contest; } \\
\text { - reflective writing }\end{array}$ \\
\hline
\end{tabular}

Each module-block is designed to form or develop various skills and abilities that ensure the ability of the future professional to convincingly and competently influence the audience through the word. Summarizing and systematizing the communicative and speech skills that are more or less formed in the first and second year students, we have identified a set of universal skills that are formed during the preparation and conduct of public speeches:

- the ability/ possession of the skill to correctly determine the communication situation;

- the ability to correctly and appropriately choose the tactics of verbal and nonverbal behavior at any level of communication: interpersonal, public, business, household, observing the laws of productive communication and applying the formulas of interpersonal, business and household communication;

- ability/ possession of the skill to conduct a dispute, participate in a discussion, polemic, debate;

- ability / mastery of the skill to competently, logically, consistently defend their views;

- ability to make a public speech on certain topics in different genres, according to the status of the audience;

- the ability to observe the etiquette models of speech without violating the socialspeech, interpersonal, communicative standard.

The result of the work, which was carried out during one semester, was the diagnosis of the social and communicative development of 80 students (20 in each focus group) who participated in the experiment, taking into account the following indicators: motivational, 
value-semantic, emotional-volitional, behavioral, cognitive, communicative-rhetorical and orthological. The descriptors of each of the listed indicators were evaluated on a 10-point scale, and then were summed up and presented as a percentage. The total points and percentages are shown in Table 4.

The students of group A were trained using experimental technology, which is based on the use of project and game learning methods in combination with active learning methods. Students of Group B mastered academic disciplines using traditional educational technologies, but within the framework of the subject «Business Communications» they also worked with the information provided in interviews with T. Chernihiv and V. Pozdner. The students of focus group B used the materials of the YouTube channels - «Cannon», «Gentle Editor» and the Internet interview with $\mathrm{Yu}$. Dudya. The participants of the focus group D mastered the educational program without the use of innovations.

Table 4. Assessment of social and communicative development of DSTU students.

\begin{tabular}{|c|c|c|c|c|c|c|c|c|c|}
\hline & \multirow{3}{*}{ Descriptors } & \multicolumn{8}{|c|}{ Focus groups } \\
\hline & & \multicolumn{2}{|c|}{ Group A } & \multicolumn{2}{|c|}{ Group B } & \multicolumn{2}{|c|}{ Groups C } & \multicolumn{2}{|c|}{ Group D } \\
\hline & & $\begin{array}{c}\text { In } \\
\text { points }\end{array}$ & In $\%$ & $\begin{array}{c}\text { In } \\
\text { points }\end{array}$ & In $\%$ & $\begin{array}{c}\text { In } \\
\text { points }\end{array}$ & In $\%$ & In points & In $\%$ \\
\hline \multirow{5}{*}{$\begin{array}{l}. \bar{J} \\
0 \\
0\end{array}$} & $\begin{array}{l}\text { Interest in collective } \\
\text { communication }\end{array}$ & 200 & 100 & 170 & 85,2 & 160 & 80 & 165 & 82,5 \\
\hline & $\begin{array}{c}\text { Ability to establish } \\
\text { friendly relationships } \\
\text { in a team }\end{array}$ & 185 & 92,5 & 180 & 90 & 136 & 68 & 150 & 75 \\
\hline & $\begin{array}{c}\text { Ability to maintain } \\
\text { social distance during } \\
\text { communicat }\end{array}$ & 179 & 89,5 & 170 & 85 & 140 & & 160 & 80 \\
\hline & $\begin{array}{l}\text { Ability to take into } \\
\text { account the } \\
\text { personality of the } \\
\text { interlocutor }\end{array}$ & 182 & 91 & 169 & 84,5 & 160 & 80 & 160 & 80 \\
\hline & $\begin{array}{l}\text { Knowledge of the } \\
\text { skills of cooperation } \\
\text { in group activities }\end{array}$ & 200 & 100 & 184 & 92 & 172 & 86 & 180 & 90 \\
\hline \multirow{5}{*}{ 哭 } & $\begin{array}{l}\text { Ability to formulate the } \\
\text { main idea of the media } \\
\text { content }\end{array}$ & 200 & 100 & 190 & 95 & 143 & 71,5 & & \\
\hline & $\begin{array}{l}\text { Ability to construct } \\
\text { reasoned, logically } \\
\text { consistent statements } \\
\text { (in oral and written } \\
\text { forms) }\end{array}$ & 165 & 82,5 & 149 & 74,5 & 120 & 60 & 130 & 65 \\
\hline & $\begin{array}{l}\text { The ability to build } \\
\text { the composition of an } \\
\text { utterance, ensuring } \\
\text { consistency and } \\
\text { coherence of the } \\
\text { presentation }\end{array}$ & 195 & 97,5 & 180 & 90 & 154 & 77 & 160 & 80 \\
\hline & $\begin{array}{l}\text { The ability to build } \\
\text { statements in } \\
\text { accordance with the } \\
\text { norms of the literary } \\
\text { language }\end{array}$ & 155 & 77,5 & 136 & 68,4 & 111 & 55,5 & 124 & 62 \\
\hline & $\begin{array}{l}\text { The ability to } \\
\text { formulate correct } \\
\text { questions in the } \\
\text { course of a } \\
\text { conversation or } \\
\text { discussion }\end{array}$ & 167 & 83,5 & 160 & 80 & 111 & 55,5 & 135 & 67,5 \\
\hline \multirow{7}{*}{ speech } & Pronouncing skills & 180 & 90 & 180 & 90 & 135 & 55 & 140 & 60 \\
\hline & $\begin{array}{l}\text { Reading technique } \\
\text { skills }\end{array}$ & 180 & 90 & 175 & 87,5 & 123 & 61,5 & 140 & 70 \\
\hline & Writing technique skills & 175 & 87,5 & 170 & 85 & 100 & 50 & 110 & 55 \\
\hline & $\begin{array}{l}\text { Correct tempo and } \\
\text { rhythm of speech }\end{array}$ & 175 & 87,5 & 170 & 85 & 123 & 61,5 & 140 & 70 \\
\hline & Grammar skills & 175 & 87,5 & 175 & 87,5 & 168 & 84 & 160 & 80 \\
\hline & Lexical skills & 180 & 90 & 180 & 90 & 146 & 73 & 150 & 75 \\
\hline & Orthoepic skills & 180 & 90 & 180 & 90 & 135 & 55 & 140 & 60 \\
\hline
\end{tabular}


When processing the obtained data, it turned out that the results of monitoring the social and communicative development of students in 4 focus groups are characterized by qualitative differences that are statistically significant. The communicative descriptors of the students of the 1st (A) and 2nd (B) focus groups, who worked with the media content of the reference native speakers, were formed at a higher level, in contrast to the participants of the 3rd group (C), who were offered interviews where bloggers popular in the Internet space acted as presenters. The degree of development of social meta-skills in students of group A differs from those of students of other groups, since in working with the 1st focus group, teachers purposefully formed or developed socially significant skills and abilities.

Thus, the results of the training of students of focus group A indicate that the proposed system of methods and techniques forms an important skill determined by a set of qualities: flexibility of thinking, a high degree of switchability from one type of activity to another, long-term memory, constructive communication with the opponent, the ability to overcome the "classroom shock", skillfully use the means of dialogization, apply the methods of active listening and successfully build reasoned, logically consistent statements both orally and in writing.

\section{Conclusion}

The proposed method meets all the requirements for it: it is realistic, reproducible and justified, corresponds to the stated goals and objectives of the planned action, and is characterized by effectiveness. The methods that make up its basis are a set of tasks and pedagogical techniques focused on the organization of the educational process and creating special conditions that motivate students to independently, proactively and creatively master the educational material in the process of cognitive activity.

The effectiveness of the methodology for developing communication and speech skills is ensured by specific tools - oral communication, topic presentation, self-presentation, debates, business games, trainings, interviews, and reflection writing.

Students of experimental group A, compared with students of control group C, have significantly greater dynamics of social skills (the indicator «Ability to establish friendly relations in a team» is $17.5 \%$ higher than in control group C) and such indicators of rhetorical skills as establishing eye contact (dynamics in experimental group A $-55 \%$, in control group $\mathrm{C}-10 \%$ ), verbal contact (55\% and $5 \%$, respectively), the use of techniques to attract the attention of listeners $(55 \%$ and $20 \%)$. The composition of the performances of the students of experimental group A has become more clear, well-thought-out, all its parts are logically connected with each other (the dynamics of this quality in the experimental group is $40 \%$, in the control group $\mathrm{C}-25 \%$ ). At the final stage of training, such quality as the correspondence of the content to the topic of the speech in the experimental group has an indicator of $100 \%$ (in the control group - $75 \%$, the dynamics of indicators is $35 \%$ and $10 \%$, respectively).

\section{References}

1. R. Prabavathi, P.C. Nagasubramani, Journal of Applied and Advanced Research, 3 (S1), 29-32 (2018), doi: 10.21839/jaar.2018.v3iS1.164

2. J. Hanson, S. Hardman, S. Luke, P. Maunders, London: Royal Academy of Engineering (2018), doi: 10.13140/RG.2.2.22598.93765

3. A.M. Goberman, S. Hughes, T. Haydock, Speech Communication, 53(6), 867-876 (2011), doi: 10.1016/j.specom.2011.02.005 
4. B. Granström, D. House, Speech Communication, 46 (3-4), 473-484 (2005), doi: 10.1016/j.specom.2005.02.017

5. E. Herbein, J. Golle, M. Tibus, I. Zetller, U. Trautwein, Contemporary Educational Psychology, 55, 176-188 (2018), doi: 10.1016/j.cedpsych.2018.09.003

6. E. Herbein, J. Golle, M. Tibus, J. Schiefer, U. Trautwein, I. Zetller, Learning and Instruction, 55, 158-168 (2018), doi: 0.1016/j.learninstruc.2017.10.008

7. A. Gallego, L. Mchugh, M. Villatte, R. Lappalainen, Journal of Contextual Behavioral Science, 16, 128-133 (2020), doi: 10.1016/j.jcbs.2020.04.003

8. D. B. McNatt, The International Journal of International Education, 17(2), 276-285 (2019), doi: 10.1016/j.ijme.2019.04.002

9. S. V. Bylkova, I. A. Kudryashov, Social Sciences, 6, 167-178 (2017)

10. S. V. Bylkova, E. P. Chubova, V. V. Kolmakova, Contemporary Research of Social Problems (Electronic Scientific Journal), 9(3), 74-96 (2018), doi: 10.12731/22187405-2018-3-74-96

11. S. V. Bylkova, Herald of Russian New University, Series «Human being in contemporary world», 1, 58-62 (2020)

12. V. Svetlana, V. Bylkova, Elena P. Chubova, Valentina V. Kolmakova, Contemporary Investigations of Social Problems (Electronic Scientific Journal), 9(3), 74-96 (2018), doi: 10.12731/2218-7405-2018-3-74-96

13. I. A. Kudryashov, E. N. Klemenova, Contemporary Investigations of Social Problems (Electronic Scientific Journal), 3(1), 53-73 (2016), doi: 10.12731/2218-7405-2016-3-5

14. S. Harrison, Journal of English for Academic Purposes, Available online 26 April 2021 https://www.sciencedirect.com/science/article/abs/pii/S1475158521000461, doi: 10.1016/j.jeap.2021.101002

15. E. Chubova, S. Bylkova, E3S Web of Conferences, 175(4), 15019 (2020) doi: 10.1051/e3sconf/202017515019

16. I. V. Kovtunenko, S. V. Bylkova, V. A. Borisenko, N. A. Minakova, V. I. Rogacheva, XLINGUA, 11(2), 95-105 (2018), doi: 10.18355/XL.2018.11.02.08

17. I. V. Kovtunenko, S. V. Bylkova, I.A. Kudryashov, E. A. Korman, Scientific Dialogue, 2, 79-94 (2021), doi: 10.24244/2227-1295-2021-2-79-94

18. E.N. Malyuga, S.N. Orlova, Linguistic Pragmatics of Intercultural Professional and Business Communication (Springer, Cham, 2018), doi: 10.1007/978-3-319-68744-5

19. K. Shokhayeva, GIAP Journals, 8(4), 1535-1548 (2020), doi: 10.18510/hssr.2020.84141 